VERTAISARVIOITU

KOLLEGIALT GRANSKAD

PEER-REVIEWED

www.tsv.fi/tunnus

\title{
TARINAN VASTAANOTTO JA AFFILIAATIO AUTISMIKIRJON HÄIRIÖSSÄ
}

\author{
Emmi Koskinen, Helsingin yliopisto, \\ valtiotieteellinen tiedekunta
}

\section{Melisa Stevanovic, Tampereen yliopisto, yhteiskuntatieteiden tiedekunta}

\begin{abstract}
Autismikirjon henkilöiden tarinankerrontaa on tutkittu sekä kokeellisin menetelmin että keskustelunanalyyttisesti, mutta tarinan vastaanottoon liittyvien käytänteiden erittely on jäänyt vähemmälle. Tässä tutkimuksessa paikataan tätä tutkimuksellista aukkoa keskittymällä erityisesti autismikirjon henkilöiden tarinan vastaanottoon ja affiliaatioon.
\end{abstract}

Aineistona on kymmenen videoitua keskustelua kahden mieshenkilön välillä, joista toisella on todettu Aspergerin oireyhtymä (AS) ja toinen on neurotyypillinen. Esittelemme keskustelunanalyyttisen tapaustutkimuksen avulla, miten kolme autismikirjon häiriöön ja sen vuorovaikutukseen liittyvää erityispiirrettä (sääntökeskeisyys, paikallissuuntautuneisuus ja egosentrisyys) heijastuvat AS-henkilöiden tapoihin ottaa vastaan vuorovaikutuskumppaninsa kertomia tarinoita ja millaisilta nämä tavat näyttävät affiliaation näkökulmasta. Lisääntynyt ymmärrys vuorovaikutuksen käytänteiden merkityksestä osallistujien toiminnan ja heidän välisensä suhteen rakentumiselle voi auttaa autismikirjoon liittyvien vuorovaikutuksen erityispiirteiden kuvaamisessa, sekä rakentaa ymmärrystä erilaisten ihmisten ja vuorovaikutustyylien välille.

Avainsanat: affiliaatio, asperger, autismikirjon häiriö, empatia, tarinankerronta, tarinan vastaanotto

\footnotetext{
Kirjoittajien yhteystiedot:

Emmi Koskinen

Melisa Stevanovic

emmi.ek.koskinen@helsinki.fi

melisa.stevanovic@tuni.fi
}

\footnotetext{
Kiitos Koneen Säätiölle tutkimuksen rahoittamisesta (Emmi Koskisen henk. koht apuraha vuosina 2018-2019). Kiitos Nuutti Harmo, Pentti Henttonen, Taina Nieminen von-Wendt, Maria-Elisa Salonsaari, Elina Sihvola, Pekka Tani ja Taina Valkeapää aineistonkeruusta. Lämpimät kiitokset Anssi Peräkylälle projektin suunnittelusta ja ohjauksesta, sekä suuret kiitokset kaikille tutkimuksen osallistujille.
} 


\section{JOHDANTO}

Affiliaation eli empaattisen samanmielisyyden tai myötäelämisen osoittaminen on tärkeää ihmisten välisten yhteyksien luomiselle ja sosiaaliselle solidaarisuudelle (Lindström \& Sorjonen, 2013; Stevanovic \& Lindholm, 2016). Yksi tärkeimpiä tällaisia tunteiden ja kokemusten jakamisen keinoja on tarinankerronta ja tarinan vastaanotto. Autismikirjon henkilöiden haasteita tarinankerronnassa on tutkittu sekä kokeellisin menetelmin (ks. esim. Diehl, Bennetto \& Young, 2006; Losh \& Capps, 2003) että keskustelunanalyyttisesti (Dean, Adams \& Kasari, 2013; Solomon, 2004), mutta tarinan vastaanottoon liittyvien käytänteiden erittely on jäänyt vähemmälle. Tässä tutkimuksessa paikataan tätä aukkoa keskittymällä erityisesti autismikirjon henkilöiden tarinan vastaanottoon ja affiliaatioon.

\subsection{Affiliaatio vuorovaikutusilmiönä}

Affiliaatiota on keskustelunanalyysin piirissä tutkittu paljon. Jeffersonin (1988; 2002) mukaan erityisesti huoltenkerronta on affiliaatiota kutsuvaa (affliation implicative), eli tämänkaltaiset kerronnat hakevat vastaanottajalta tukea, sympatiaa ja samanmielisyyttä (Jefferson, 2002, s. 1349). Stivers (2008) toi affiliaation käsitteen koskemaan kaikkea tarinankerrontaa. Kertojat usein käsittelevät kuvailemiaan tapahtumia jostakin tietystä emotionaalisesta näkökulmasta käsin: kertomus voidaan esittää esimerkiksi hauskana, surullisena tai innostavana sattumuksena. Affiliaation osoittamisessa olennaisinta on kertojan affektiivisen asennoitumisen (affective stance) jakaminen - sen poimiminen, mikä kerronnassa on ollut affektiivisesti merkittävää, vaikka tämä oltaisiin tuotu esiin vain implisiittisesti (Stivers, 2008). Lisäksi oleellista on, että tarinan vastaanottaja asettuu kertojan kanssa ikään kuin samalle puolelle (Jefferson, 2002), ei moralisoi tai pelkästään jaa neuvoja.

Affiliaation merkitys kertojalle tulee näkyväksi erityisesti tilanteissa, joissa vastaanottajat eivät ilmaise affiliaatiota. Tällöin kertojat saattavat jäädä eri tavoin hakemaan heiltä tällaisia reaktioita (Couper-Kuhlen, 2012; Peräkylä \& Ruusuvuori, 2012; Selting, 2010). Affiliaation puute ei ilmene ainoastaan vuorovaikutuksen pintatasolla, vaan myös mahdollista stressiä indikoivana psykofysiologisena aktivaationa kertojan ruumissa (Peräkylä ym., 2015; Stevanovic ym., 2019). Affiliaation ilmaiseminen ei silti aina ole suoraviivaisen yksinkertaista, sillä sen ilmaisemisen tarkka ajoitus ja ajallinen kesto ovat asioita, jotka vaativat kerronnan vastaanottajalta erityistä tarkkaavaisuutta. Samalla tavoin affiliaatiivisestä puheesta ei voi siirtyä arkisempaan puheeseen "noin vain", vaan tällaisten siirtymien on todettu olevan rituaalisesti säänneltyjä (Holt, 1993; Jefferson, 1984; Maynard, 1997; Selting, 2010).

Affiliaation ilmaisemiseen on monia keinoja. Keholliset affektin ilmaisemisen keinot, kuten kasvonilmeet, henkäykset ja emotionaalinen äänenlaatu, tarjoavat kerronnan vastaanottajalle välittömän keinon ilmaista empaattista myötäelämistä (Peräkylä, 2016; Stevanovic, 2016). Tässä artikkelissa kuitenkin tarkastelemme affiliaatiota ensisijaisesti osallistujien puheenvuoroina, jotka tukevat kertojan affektiivista asennoitumista. Tällaiset puheenvuorot ovat odotuksenmukaisia sekä tarinan aikana että erityisesti sen lopussa (Goodwin \& Goodwin 1992; Stivers, 2008; ks. myös Stivers, Mondada \& Steensig, 2011).

\subsection{Aspergerin oireyhtymä ja autismikirjon häiriö}

Aspergerin oireyhtymä (AS) on autismikirjoon kuuluva neurobiologinen kehityshäi- 
riö. ${ }^{1}$ Asperger-henkilöistä 1940-luvulla tehtyä alkuperäistä profiilia luonnehti empatian puute, kyvyttömyys luoda ystävyyssuhteita, yksipuolinen keskustelu, rajoittuneet ja intensiiviset kiinnostuksenkohteet sekä motorinen kömpelyys (Asperger, 1944; Wicker \& Gomot, 2012). Nykyään tiedetään, että autismikirjon henkilöt voivat tunnetasolla olla hyvinkin empaattisia tai jopa yliempaattisia (ks. esim. Markram, Rinaldi \& Markram, 2007), mutta kokeellinen tutkimus on osoittanut, että heillä on neurotyypillisiä enemmän vaikeuksia nähdä tilanteita muiden näkökulmasta (Brewer, Young \& Barnett 2017), mikä on oleellista affiliaation ja empatian osoittamisessa. Autismikirjon henkilöillä on usein myös vaikeuksia tunnistaa puhekumppanin affektiivista prosodiaa ja ei-kielellisiä merkkejä (Korpilahti ym. 2007; Kujala, Lepistö, Nieminenvon Wendt, Näätänen \& Näätänen, 2005). Affektiivisuuteen liittyvien haasteiden lisäksi autismikirjon henkilöiden käyttäytymistä ja vuorovaikutusta luonnehtii myös muita erityispiirteitä, joiden suhde affektiivisuuteen ei ole täysin selvä, ja jotka eivät näyttäydy vain vuorovaikutuksen ongelmina. Seuraavaksi esittelemme kolmea tällaista piirrettä.

Yksi autismikirjon häiriöön vahvasti kuuluva piirre on sä̈ntökeskeisyys - se, että rutiinit, rituaalit ja säännönmukaisuus ovat usein tärkeitä AS-henkilöiden arkielämälle (Attwood, 1998; Gillberg, 2002; Tani, Nieminen-von Wendt, Lindberg \& von Wendt, 2004). Sosiaaliseen vuorovaikutukseen liittyvät lukuisat, kirjoittamattomat säännöt aiheuttavat

\footnotetext{
1 Toukokuussa 2013 julkaistuun psykiatrisen tautiluokituksen (Diagnostic and Statistical manual of Mental disorders, DSM) uusimpaan versioon lisättiin autismikirjon häiriön luokka, jonka myötä Asperger omana diagnoosinaan jäi pois (APA, 2013). Suomessa käytössä oleva tautiluokitus ICD-11 tulee seuraamaan DSM:n jalanjäljissä (WHO, 2019). Diagnostiset kriteerit uudelle autismikirjon häiriön luokalle ovat vaikeudet vastavuoroisessa sosiaalisessa vuorovaikutuksessa sekä rajoittuneet, toistavat ja kaavamaiset toiminnot tai kiinnostuksen kohteet (APA, 2013).
}

kuitenkin haasteita AS-henkilöille, sillä vuorovaikutus on vahvasti kontekstisidonnaista ja sääntöihin tehdään jatkuvasti poikkeuksia kulloisenkin tilanteen mukaan (Stevanovic \& Koskinen, 2018). AS-henkilöt saattavat esimerkiksi pitäytyä totuuden puhumisen normissa aina ja kaikissa tilanteissa, vaikka tilanne vaatisi hienotunteisuutta tai jopa valkoista valhetta (Gillberg, 2002). AS-diagnoosiin liittyy myös taipumus niin sanottuun moraaliseen systemointiin ja "ilmiantamiseen" (whistleblowing, Baron-Cohen, 2008, s. 68). Sääntökeskeisyyden ansiosta autismikirjon henkilöillä voi kuitenkin olla myös erityistä lahjakkuutta esimerkiksi matemaattisissa aineissa tai yleisten säännönmukaisuuksien ja rakenteiden havaitsemisessa (Baron-Cohen, 2008).

Toisesta autismikirjoon liittyvästä piirteestä voi käyttää termiä paikallissuuntautuneisuus. Keskustelijat yleisesti suuntautuvat normiin, jonka mukaan vuorovaikutustoiminnan kokonaisuus on tärkeämpää kuin sen pienet yksityiskohdat. Autismikirjon henkilöiden on kuitenkin esitetty toimivan päinvastoin siten, että yksityiskohdat saavat päähuomion (Maynard, 2005). Käsitys saa empiiristä tukea myös silmänliiketutkimuksista, joissa autismikirjon lasten on havaittu kiinnostuvan yksityiskohdista neurotyypillisistä poikkeavalla tavalla (Klin, Jones \& Schultz, 2003). Ochs ja Solomon $(2005$; 2010) tutkivat etnografisesti lapsia, joilla oli diagnosoitu joko autismi tai Aspergerin oireyhtymä. Heidän mukaansa lapset usein tuottivat keskusteluun vuoroja, jotka olivat niin sanotusti läheisrelevantteja (proximally relevant) - kontribuutiot eivät siis olleet täysin asiayhteyteen istuvia, mutta ne eivät olleet täysin aiheen vierestäkään (Ochs \& Solomon, 2005, s. 157-158). Yksi tapa, jolla tämä ilmeni, oli juuri paikallissuuntautuneisuus: lasten kommentit saattoivat liittyä hyvin oleellisesti johonkin juuri äsken mainittuun, mutta vuorot eivät olleet koherentteja koko keskustelun aihetta ajatellen. Toisaalta tällai- 
set paikallissuuntautuneet vuorot tai muut autismikirjon henkilöiden asiayhteyden vierestä näyttäytyvät kontribuutiot voivat toimia myös vuorovaikutuksen välineinä (ks. Dindar, Korkiakangas, Laitila \& Kärnä, 2016ab; Muskett \& Body, 2013; Muskett, Perkins, Clegg \& Body, 2010; Ochs \& Solomon, 2010; Stribling, Rae \& Dickerson, 2007).

Kolmatta autismikirjoon ja sen vuorovaikutukseen liittyvää piirrettä voi kuvata esimerkiksi termillä egosentrisyys. Yksi varhaisimpia autismikirjon häiriön merkkejä on lapsen vähäinen kiinnostus toisia lapsia kohtaan: lapsi saattaa leikkiä lähinnä yksin ja keskittyä intensiivisesti vain omiin aktiviteetteihinsa (Gillberg, 2002). Egosentrisyys voi näkyä vuorovaikutuksen tasolla esimerkiksi jonkin tietyn puheenaiheen itsepintaisessa ylläpitämisessä keskustelukumppanin aiheenvaihdon yrityksistä huolimatta - varsinkin jos aihe sattuu koskemaan henkilön omaa erityistä kiinnostuksen kohdetta (Attwood, 1998; Paul, Orlovski, Marcinko \& Volkmar, 2009). Autismikirjon henkilöiden puhe saattaa myös olla luonteeltaan lähinnä instrumentaalista, eli johonkin tiettyyn itselle tärkeään tavoitteeseen tai tehtävään liittyvää (Tager-Flusberg, 1996), vastakohtana esimerkiksi tunteiden ja kokemusten jakamisen motiiveille (Gutstein, 2001). Myöskään egosentrisyys ei kuitenkaan ole lähtökohtaisesti vain ongelmallista, sillä autismikirjon henkilöiden omista kiinnostuksenkohteista puhuminen saattaa tietyissä tilanteissa sujuvoittaa keskustelun kulkua ja ylläpitää vuorovaikutusta sen sijaan, että se olisi vuorovaikutukselle haitallista monologia (Stevanovic ym., 2017; ks. myös. Stribling, Rae, Dickerson \& Dautenhahn, 2006).

Keskustelunanalyysin (KA) potentiaali autismikirjon tutkimuksessa on monipuolinen (ks. katsaukset O 'Reilly, Lester \& Muskett, 2016; Stevanovic \& Koskinen, 2018). KA-tutkimuksessa korostuu toiminnan rakentuminen yhdessä muiden kanssa, jolloin autismikirjon henkilöiden epätyypillisenä tai ongelmallisenakin pidettävä toiminta voi näyttäytyä mielekkäänä. Viimeaikainen multimodaalinen vuorovaikutustutkimus onkin havainnollistanut autismikirjon henkilöiden erityisiä kompetensseja ja tapoja kommunikoida toisten kanssa (ks. Dindar ym., 2016ab; Korkiakangas, 2018; Korkiakangas, Rae \& Dickerson, 2012; Muskett ym., 2010; Muskett \& Body, 2013; Striblingym., 2006; Stribling, Rae \& Dickerson, 2007). Luonnollisen vuorovaikutusaineiston analyysi on lisäksi osoittanut, että autismikirjon henkilöiden vuorovaikutuskompetenssit tulevat tosielämän vuorovaikutustilanteissa paremmin esille kuin kokeellisissa tilanteissa (Dindar ym., 2016b; Korkiakangas \& Rae, 2014).

Oman tutkimuksemme aineistoa voi luonnehtia puolikokeelliseksi: se ei ole perinteisen KA-tutkimuksen suosimaa, täysin naturalistisesti ilmenevää (Potter, 2004) puhetta, mutta kyseessä on silti vapaamuotoinen keskustelu, eikä esimerkiksi kysely tai strukturoitu haastattelu. Koska keskustelijat eivät tunteneet toisiaan entuudestaan, vuorovaikutuksessa ilmeni ajoittaista "kankeutta". Huomattavaa on kuitenkin se, että sama kankeus koski sekä niitä keskusteluja, joissa toisella osallistujalla oli todettu Asperger, että niitä, joissa molemmat keskustelijat olivat neurotyypillisiä. Merkille pantavaa on myös se, ettei keskustelijoiden tarvinnut ottaa huomioon henkilökohtaista vuorovaikutushistoriaansa ja muita toistensa tuntevien ihmisten vuorovaikutukseen liittyviä sosiokulttuurisia ulottuvuuksia, joissa autismikirjon henkilöillä on todettu olevan erityisiä vaikeuksia (Ochs, Kremer-Sadlik, Gainer Sirota \& Solomon, 2004), minkä vuoksi osallistujien neurologiset statukset eivät aineistossamme korostuneet. Päinvastoin, tutkimukseemme rekrytoidut AS-henkilöt olivat kielellisesti hyvin lahjakkaita ja he puhuivat keskustelujen aikana vähintään yhtä paljon kuin neurotyypilliset kumppaninsa. 
Myös heidän älykkyysosamääränsä oli normaali.

Edellä mainituista seikoista johtuen oman tutkimuksemme kohdistaminen AS-henkilöiden kompetensseihin ei olisi voinut tarjota vastaavanlaista uutta tietoa, kuin monet aikaisemmat autismikirjoa käsittelevät keskustelunanalyyttiset tutkimukset ovat tehneet. Sen sijaan aineistomme voi kuitenkin ainutlaatuisella tavalla mahdollistaa neurotyypillisten ja "high functioning" AS-henkilöiden vuorovaikutuskäytänteiden vertailun kontekstiltaan samanlaisissa tilanteissa (Koskinen, Stevanovic \& Peräkylä, tulossa). Olemme yhtä mieltä O’Reillyn, Lesterin ja Muskettin (2016) kanssa siitä, että keskustelunanalyysin tarkan analyyttisen fokuksen avulla voidaan myös laajentaa, täydentää, ja hienosäätää aikaisemman tutkimuksen sekä autismikirjon diagnostisien kriteereiden viitoittamia vuorovaikutuksen erityispiirteitä ja nähdä, miten ne mahdollisesti näkyvät vuorovaikutuksen mikrotasolla (emt., s. 358, ks. myös Dobbinson, 2005; Hobson, Hobson, Garcia-Perez \& Du Bois, 2012).

Autismikirjon erityispiirteet ovat tärkeitä sosiaalisen vuorovaikutuksen rakenteiden kannalta, ja ne saattavat siis potentiaalisesti liittyä AS-henkilöiden tarinan vastaanottoon ja affiliaation osoittamiseen. Tämän tutkimuksen tarkoitus on selvittää, kuinka yllä esitellyt autismikirjon häiriöön liittyvät erityispiirteet - sääntökeskeisyys, paikallissuuntautuneisuus ja egosentrisyys - heijastuvat AS-henkilöiden tapoihin ottaa vastaan vuorovaikutuskumppaninsa kertomia tarinoita ja millaisilta nämä tavat näyttävät affiliaation näkökulmasta.

\section{AINEISTO JA MENETELMÄT}

Laajempana aineistona on kymmenen videoitua keskustelua kahden mieshenkilön välillä, joista toisella on todettu Aspergerin oireyhtymä (AS-NT dyadit), sekä yhdeksän kontrollikeskustelua, joissa molemmat osallistujat ovat neurotyypillisiä (NT-NT dyadit). Keskustelut kestivät 45-60 minuuttia, ja ne on sittemmin litteroitu käyttäen keskustelunanalyyttistä litterointimenetelmää (Seppänen, 1997). Litteraateista on poistettu tai muutettu tunnistetiedot ja erisnimet, kuten koulujen tai paikkakuntien nimet. Erillistä tutkimusta varten (ks. Stevanovic ym., 2019) mitattiin myös osallistujien psykofysiologisia reaktioita neljällä mittarilla, jotka olivat sydämen lyöntitiheys, kasvolihasten toiminta, ihon sähkönjohtavuus kämmenessä ja hengitystaajuus. Mittalaitteet olivat kevyitä ja osallistujat saivat puhua ja liikuttaa käsiään keskustelun aikana täysin normaalisti.

Ennen koetta osallistujat saivat tietoa tutkimuksesta ja allekirjoittivat suostumuslomakkeen. Keskustelun aikana osallistujat istuivat suljetussa huoneessa vastakkaisissa nojatuoleissa. Keskustelun aiheena olivat osallistujien oman elämän tapahtumat: iloiset, onnelliset tapahtumat ja menetykset. Osallistujat saivat itse valita, miten he aiheesta keskustelivat. Tarkempaa keskustelun aihepiiriä, tyyliä tai muotoa ei ohjeistettu, vaan keskustelun todettiin oleva tutkimuksen kannalta hyvä sellaisena, kun se sattuu etenemään. Kontrolliryhmän jäsenet tiesivät keskustelleensa AS-henkilön kanssa ja asetelma oli selvä myös AS-henkilöille.

Tutkimukseen rekrytoitiin vapaaehtoisia 18-40-vuotiaita miehiä. AS-ryhmän henkilöt rekrytoitiin aiempiin tutkimuksiin osallistuneista ryhmistä, joille oli tehty tarkat neuropsykologiset tutkimukset sekä ASdiagnoosin määritykset ICD-10:n (WHO, 1993) mukaan. Kontrolliryhmän osallistujat olivat opiskelijoita, jotka rekrytoitiin sähköpostilistoille suunnattujen tiedusteluiden avulla. Kontrolliryhmän osallistujien neurotyypillinen status varmistettiin käyttämällä autismi-, empatia- ja systemointiosamäärää 
mittaavia kyselyjä (Baron-Cohen, Richler, Bisarya, Gurunathan \& Wheelwright 2003; Baron-Cohen \& Wheelwright, 2004; BaronCohen, Wheelwright, Skinner, Martin \& Clubley 2001). Tutkimuslupa saatiin Helsingin yliopistollisen keskussairaalan eettiseltä toimikunnalta (päätös: 21.09.2011).

Keskusteluaineisto osoittautui hyvin rikkaaksi ja monipuoliseksi, ja keskusteluissa kerrottiin paljon erilaisia tarinoita. Tarinat koskivat osallistujien henkilökohtaista elämää, ystäviä, sukulaisia tai vaikka televisioohjelmia ja kuulopuheita. Kaikki kerrotut tarinat eivät siis suinkaan koskeneet yksinomaan ohjeistuksessa mainittuja onnellisia asioita tai menetyksiä, vaan tarinat saattoivat olla myös hyvin arkisia tai hauskoja.

Tässä tutkimuksessa keskitytään AS-NT keskusteluihin $(\mathrm{N}=10)$ ja erityisesti neurotyypillisten osallistujien tarinoihin, joissa AS-henkilöt ovat vastaanottajan roolissa $(\mathrm{N}=123)$. Tarinakokoelma pitää sisällään sekä pidempiä narratiiveja että lyhyempiä anekdootteja ja kertomuksia, joissa kertoja ottaa affektiivisen asennoitumisen kertomaansa kohtaan, ja jotka siten kutsuvat vastaanottajaa affiliaatioon (Stivers, 2008). Menetelmänä tutkimuksessa käytetään keskustelunanalyysia (Schegloff, 2007; Sidnell \& Stivers, 2013), joka tarjoaa systemaattisia työkaluja tarkastella keskustelun osanottajien vuoro vuorolta etenevää toimintaa tarinan kertojina ja vastaanottajina (Routarinne, 1997, s. 138-139). Esittelemme tulokset tapaustutkimuksena yhdestä kertomuksesta, joka ilmentää aineistossa kauttaaltaan esiintyviä ilmiöitä, vaikkakin omassa ainutlaatuisessa muodossaan.

\section{TULOKSET}

Tulosluku jakautuu neljään esimerkkikatkelmaan, jotka yhdessä esittelevät, miten sääntökeskeisyys, paikallissuuntautuneisuus ja egosentrisyys näkyvät erään AS-henkilön tavassa vastaanottaa neurotyypillisen (NT) vuorovaikutuskumppaninsa tarina. Näitä piirteitä esiintyy osin rinnakkain ja samanaikaisesti, mutta selkeyden vuoksi käsittelemme niitä seuraavassa yksitellen. Esimerkit ovat kronologisessa järjestyksessä, joten NT-henkilön kertoman tarinan voi lukea kokonaisuudessaan (lukuunottamatta pieniä hetkiä, joiden aikana keskustelu etääntyi päätarinasta). Jokaisen esimerkin analyysissa otetaan kantaa myös vastaanottovuorojen affiliatiivisuuteen sekä relevanssiin tarinan emotionaalisen sisällön kannalta.

Esimerkki 1 alkaa kontekstissa, jossa molemmat keskustelijat ovat juuri todenneet, etteivät ole koskaan menettäneet läheisiä ihmisiä. Kertoja (NT) sanoo, että hänellä tämä tilanne on kuitenkin ollut hyvin lähellä, kun hänen paras kaverinsa sai työmaalla kaivinkoneen kauhan päähänsä. Tarina alkaa tästä. 


\section{Esimerkki 1: Sääntökeskeisyys}

\section{NT = Neurotyypillinen henkilö (kertoja) \\ AS= Asperger-henkilö (vastaanottaja)}

\section{A1 Kaivinkone 1/4}

$01 \mathrm{NT}$ : mul oli semm[onen,

02 AS: [\#ӧö\#

$03 \quad(0.3)$

04 NT: mis oli aika läheltä (0.4)

05 läheltäpiti-tilanne ku (.) paras kaveri (0.8)

06 sai tollasen $\uparrow$ kaivinkoneen kauhan päähän (0.7)

07 tuo- tuol työmaalla, (0.6) ja, (0.4) sillä

08 murtu $\uparrow$ selkä niinku ihan täysin ja, (0.4) ja

09 tota: (0.5) se oli, (1.5) hyvä tuuri vaan kävi

10 ettei halvaantunu tai kuollu (0.3) ensinnäkään

11 (.) ku oli kypärä päässä mut, (0.8) mut sillä

12 niinku, (0.7) hajos puolet selkärankaa ja (0.4)

13 ja (0.3) se oli sillee (0.6) oli $\uparrow$ seki aika

$14(1.0)$ <surulline> (0.4) paikka sillee ja, (0.3)

15 mut et toisaalta siin on sit taas se et, (1.0)

16 et (0.3) se oli ihme et se ei kuollu koska

17 (0.4) sil sattu olee kypärä pääs ku: (0.3) se

18 oli Oulun kau-kaupungin katuosastol ja,

19 (1.3) n-ne ei hirveesti pitäny s'tä mut sit ne

20 oli nii lähel keskustaa sii vaihees et ne pisti

21 kypärät sinä päivänä päähä ja, (0.5) just

22 sillon tuli se kauha sit päähä ni, (0.3) ni

23 t'ta sen takii säästy henki et siinä ois, (0.9)

24 kypärä meni ihan (0.3) säpäleiks mut siin ois

25 niinku pää hajonnu mut,

$26 \quad(1.0)$

27 AS: ai totae:s (0.4) ne oli lähel keskustaa j' sit

pani kypärän [päähän ni, ]

29 NT: [nii sen ta]kii et (.) et näyttää

hyvält. (0.4) et [ei muuten pidetä]

31 AS: [ [ai kuitenki) ]

$32(0.8)$

$33 \mathrm{NT}$ : ja mut sen [jälkee on varmaa] pidetty et toi=

34 AS: [ [aika -$)]$

$35 \mathrm{NT}$ : =oli (.) tosi (0.3) harvinainen tapaus et se

36 (0.6) kaivinkoneen kauha jotenki, (0.7) se 
Tarinoiden johdantosekvenssit usein ennakoivat tulevaa kertomusta ja sen merkitystä (Heritage 2011; Sacks, 1974). NT luonnehtiikin kertomustaan "läheltä piti" -tilanteeksi (rivi 5), mikä toimii tulkintaohjeena siitä, miten tarinaan tulisi suhtautua. Tätä luonnehdintaa seuraa tapahtumakuvaus siitä, miten kertojan paras ystävä sai kaivinkoneen päähänsä ja "sillä murtu selkä niinku ihan täysin" (rivi 8). Tämä melko vahva kuvaus ei saa AShenkilöltä verbaalista eikä myöskään nonverbaalista vastaanottoa (kuten ilmeitä tai tunnistettavia eleitä). Tämän jälkeen NT nostaa esiin tarinan kääntöpuolen siitä, miten hyvä onni ystävällä kävi, ettei hän halvaantunut tai kuollut, mihin oli syynä hänen päässään onnettomuushetkellä ollut kypärä (rivit 9-11). AS ei reagoi kertomukseen eikä tuota esimerkiksi minimipalautteita (“mm”, “niin”) tai nyökkäyksiä, jotka osoittaisivat kuulolla oloa ja/tai affiliaatiota (Sorjonen, 2001; Stivers, 2008). NT palaa tämän jälkeen tapahtuman traagisuuteen toistamalla, että kaverilla "hajos puolet selkärankaa” (rivi 12) ja tekee tarinan emotionaalisen puolen vielä selvemmäksi sanomalla, että se oli "aika surulline paikka sillee ja” (rivi 14). AS-henkilö ei edelleenkään ilmaise vastaanottajuuttaan sanallisesti tai kehollisesti. Tämän jälkeen NT peruuttaa surullisuudesta (rivit 15-16) toteamalla "mut et toisaalta siin on sit taas se et se oli ihme et se ei kuollu” ja lisää, että juuri sinä päivänä heillä oli sattumalta kypärät päässä (rivi 17). Tässä vaiheessa korostuu jälleen, miten ystävällä oli onni matkassa. Seuraavaksi NT kertoo vielä tarkemmin (rivit 18-25), miten juuri onnettomuuspäivänä kypärät olivat työmiehillä käytössä ja säästivät ystävän hengen.

Yhden sekunnin mittaisen tauon (rivi 26) jälkeen AS ottaa vuoron itselleen: "Ai tota, ne oli lähel keskustaa ja sit pani kypärän päähän ni” (rivit 27-28). Tämä vuoro kutsuu selvennystä tai mahdollisesti jopa kyseenalaistaa sen, miten keskustan lähellä oleminen liittyy kypärän käyttämiseen. NT selventää asian (rivit 29-30) ja jatkaa, että nykyään kypäriä kyllä käytetään muutoinkin (rivi 33). Tämän kanssa päällekkäispuhuntana (rivi 34) AS sanoo"aika-" (mahdollisesti, puhe on hiljaista), joka saattaisi olla johtamassa kypärän käyttöä evaluoivaan vuoroon, mutta AS:n ääni hiipuu pois ja vuoro jää siten epäselväksi. AS:n viiveellä tuottama tarinan vastaanottovuoro (rivit 27-28) ei siis tartu kertomuksen emotionaaliseen sisältöön, vaan affiliaation osoittamisen sijaan topikalisoi kypärän käytön ja mahdollisesti siihen liittyvän sääntörikkomuksen. Kypärän käyttäminen on todella relevantti tarinan emotionaalisen puolen kannalta, koska se säästi ystävän pahemmilta vammoilta tai jopa kuolemalta. AS:n vastaanoton voi kuitenkin kuulla pikemminkin kyseenalaistavan syyn miksi kypärä on aiemmin ollut pois, kuin myötäelävän tätä “onni onnettomuudessa" -asennoitumista.

Vastaanottovuorollaan kuulija tyypillisesti osoittaa sen, miten hän on kertomuksen ymmärtänyt, jolloin kertoja voi joko hyväksyä tulkinnan tai täsmentää kertomuksensa kärkeä (Routarinne, 1997, s. 150; Sacks, 1974). Vastattuaan AS:n tiedusteluun kypärästä NT palaa omaan kertomukseensa ja tarjoaa nyt enemmän yksityiskohtia tapahtuneesta (alkaen riviltä 35). Tällä tavoin vastaanottaja saa uuden tilaisuuden vastata affiliatiivisesti (Jefferson, 1978, ks. myös Heritage, 2011). 


\section{Esimerkki 2: Paikallissuuntautuneisuus}

\section{$\underline{\text { A1 Kaivinkone } 2 / 4}$}

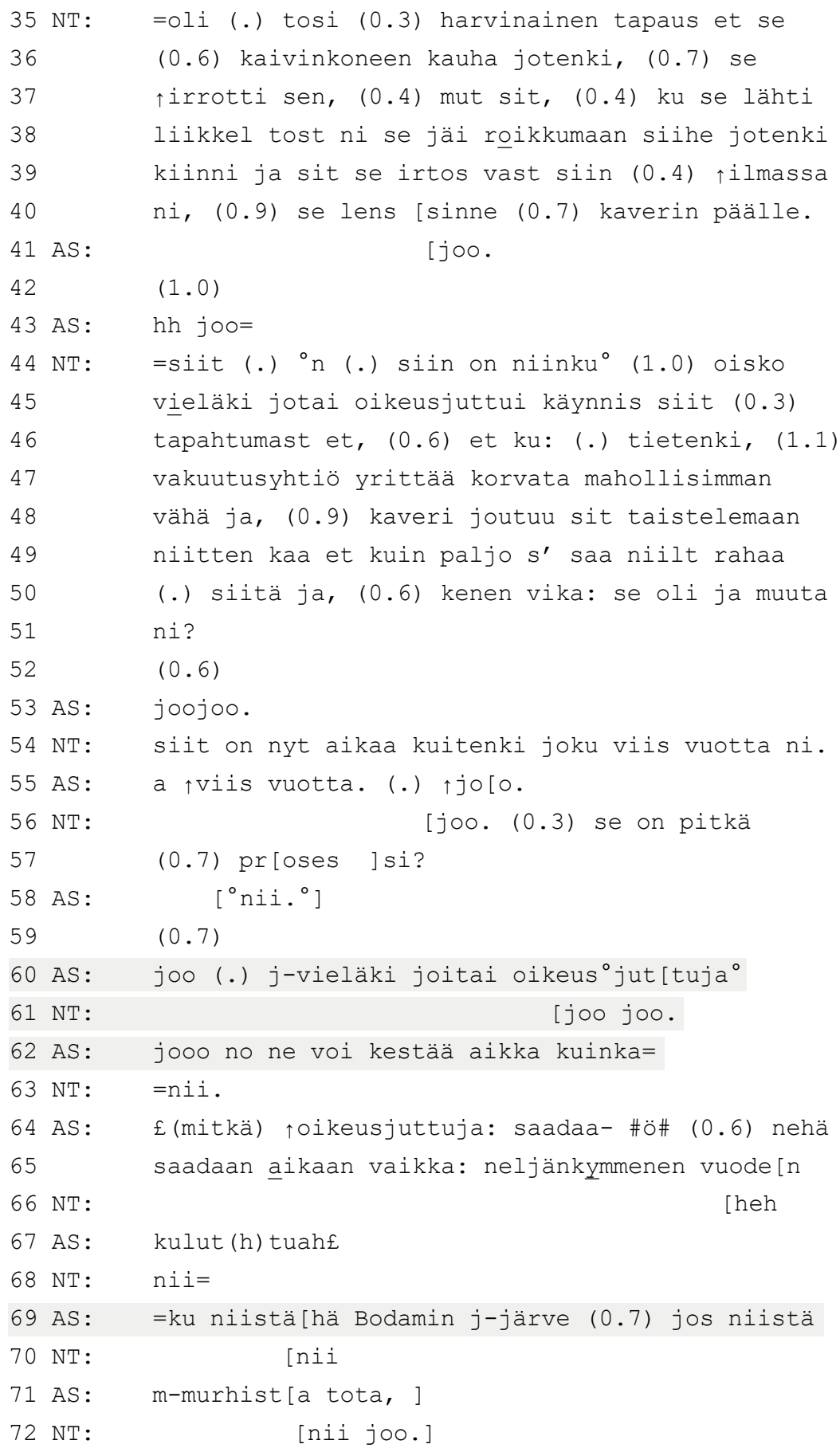


NT:n yksityiskohtaisempi kuvaus kaivinkoneonnettomuuteen liittyvistä tapahtumista (rivit 37-40) saa AS:Ita kuulolla oloa ilmaisevia minimipalautteita (“joo”, riveillä 41 ja 43). NT jatkaa kerrontaa edelleen, kun hän lisää tarinaansa kaverin kokemista vastoinkäymisistä vielä taistelun vakuutusyhtiön kanssa (rivit 44-51). Tämä uusi ulottuvuus saa AS:Ita jälleen neutraalin vastaanoton “joojoo” (rivi 53). NT kuitenkin jatkaa vielä ja viittaa taistelun pitkään ajalliseen kestoon ("siit on nyt aikaa kuitenki joku viisi vuotta ni"), ja AS tarttuukin tähän aiempaa affektiivisemmin ensin yllättymistä ilmaisevalla toistollaan (“a viis vuotta joo”, rivi 55), ja sitten NT:n vahvistuksen ja pienen tauon jälkeen (rivi 59) uudella vahvistusta hakevalla vuorollaan ("vieläki joitai oikeusjuttuja", rivi 60). Tämän jälkeen AS siirtää aiheen ensin pitkiin oikeusjuttuihin yleensä (rivit 62-67), ja sitä kautta Bodominjärven murhiin (rivi 69 eteenpäin).

AS:n vuoro (rivi 62) jakaa NT:n affektiivisen asennoitumisen pitkien oikeusjuttujen vaikeudesta, mutta toisaalta myös kuvaa ne tavallisiksi ja melko yleisiksi asioiksi ("jooo no ne voi kestää vaikka kuinka”, rivi 62). AS jatkaa asemoimalla pitkät oikeusjutut järjettömiksi asioiksi, mihin viittaa AS-henkilön huvittunut hymyily rivin 64 lausuman aikana sekä "ky"-tavun selvä painotus kohdassa "nehän saadaan aikaan vaikka neljän kymmenen vuoden kuluttua" (rivi 65). NT seuraa tätä uutta huvittunutta linjaa (ks. naurupartikkeli, rivi 66), minkä myötä AS rakentaa siirtymän Bodominjärven murhiin (rivi 69), jonka aiempi viittaus (rivillä 65) mahdollistaa. AS:n puhe Bodominjärven murhista on topikaalisesti paikallissuuntautunutta, eli se liittyy tiiviisti juuri äsken puhuttuun, mutta ei ota enää huomioon laajempaa keskustelukehystä NT:n ystävästä. NT kohteleekin tätä murhia koskevaa, melko laajamittaista (yht. 40 riviä) keskustelun osiota loppupeleissä sivusekvenssinä suhteessa aiemmin kertomaansa (ks. esimerkki 3).
AS:n puhetta Bodominjärven murhista voi tarkastella myös niin sanottuna toisena kertomuksena (Sacks, 1992). Kertomukset esiintyvät keskustelussa usein ryppäinä tai tarinakierroksina (Goffman, 1974; Tannen, 1984), ja ensimmäisen kertomuksen jälkeen kerrotut tarinat puhuvat tyypillisesti samasta aiheesta, ja kertojan asenne kertomusta kohtaan on samankaltainen. Toinen kertomus osoittaa siis kuuntelijan tulkintaa siitä, miten hän on kuullut edellisen kertomuksen (Routarinne, 1997, s. 152-155; Sacks, 1992). Tässä tapauksessa AS käyttää NT:n kertomuksen loppuosan yksityiskohtaa kimmokkeena omalle kerronnalleen (vrt. Jefferson, 1984) ja hyödyntää pitkien, järjettömien oikeusjuttujen kehystä sen sijaan, että kehystäisi tarinansa laajemmin esimerkkinä vastoinkäymisistä elämässä (ks. myös Koskinen, 2015). 


\section{Esimerkki 3: Egosentrisyys}

\section{A1 Kaivinkone 3/4}

$113 \mathrm{NT}:$

114

115

116 AS :

$117 \mathrm{NT}$ :

118

119

120

121

122

123

124

125

126

127

128

129 AS:

$130 \mathrm{NT}$ :

131

132

133

134 AS:

135

136 AS :

137

138

139

$140 \mathrm{NT}:$

141 AS :

$142 \mathrm{NT}$ :

143 AS:

$144 \mathrm{NT}$ :

145

146 AS:

$147 \mathrm{NT}$ :

148

149

150

151 AS :

$152 \mathrm{NT}$ : [mut tosiaan kaveri niinku, (0.8) on (0.5) silleen $\uparrow$ hyvin kuntoutunu et, (0.4) käy[dään pelaa fudista ja muuta sen kaa et, $[$ joo (0.8) et (0.4) silläki oli toi, (0.5) se harrasti (0.9) uuintia kans niinku, (1.2) oisko se ollu $\uparrow$ yhen sijan rankingis mua alempaa et just siin (0.8) aika lähel ainaki maajoukkuetta ja, (1.3) ja maajoukkueessaki pääsi edustaa mut sit se loppu se, (0.7) urheilemine siihe ja, (0.9) alko kuntoutus et. (1.7) vuoden verra joutu pitää semmost (.) metalli (0.5) rankaa tuol niinku, (0.5) selkärangan ympäril. (1.1) et se: (0.3) palautuu ne (.) luut sinne ja, (1.2) ja tota, (0.6) ${ }^{\circ}$ tietty leikkauksii ja tollee mut et ${ }^{\circ}(1.3)$ [nyt on aika hyväs kunnos ja (0.3) ${ }^{\circ} \mathrm{ni} \mathrm{i}^{\circ}$ just (.) täält (0.3) koulust valmistu vuos sit ni: (1.0) ihan (0.5) hyvin pysty kuitenki koulun käymää?

$(0.7)$

joojoo.

(1.3) jooj-öö eihä se tota (0.7) eihä se ka- eise- 'ota (0.3) \#e\# kaivinkonenkaa kauha näy- näytä itseasias yhtään (0.6) 'äytä yh (yh) [tää tota, ]

[joo mut se] painaa viissataa kiloo £nih£ tää eij s'tä: ei [jaksan- (0.6) s'tä ei kai [se o-

jaksa $\uparrow$ nostaa [niinku ite] ollenk[aa [joo ei ] [ei todellak[aa.

[zeh (0.9) näyttää yllät [tävän kevyel[tämmönen

$\uparrow$ nojatuollin kokonen mut (.) umpirautaa ni

(0.3) sehän £painaah.£

$(0.5)$

^nojatuolin kyllä jaksaa nos[taa.

[nit. 


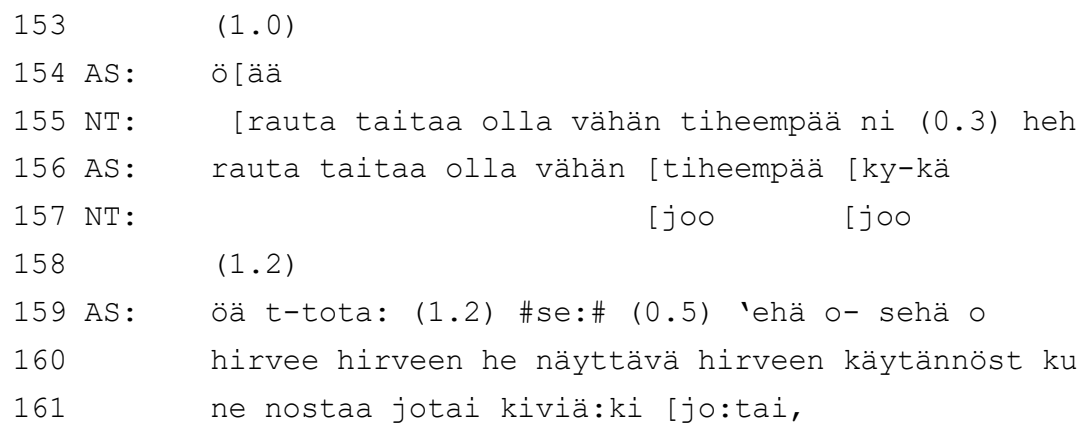

Kun Bodomjärven murhat on käsitelty, NT siirtää keskustelun jälleen takaisin ystävänsä tilanteeseen. NT aloittaa vuoronsa "mut tosiaan" -fraasilla, jota voi pitää osoituksena siitä, että jokin projekti on edelleen kesken, mihin nyt palataan (rivi 113). Tätä seuraa niin sanottu "bright side" -sekvenssi (Holt, 1993; Maynard, 1997), jossa NT kertoo, että kaveri on kuntoutunut hyvin. Huolenkerronnan yhteydessä asioiden myönteisen puolen esiintuominen toimii usein topiikin lopettamisen työkaluna (emt.). NT kuitenkin jatkaa huomiolla, että prosessi on ollut pitkä ja raskas, ja hänen ystävänsä paikka uintimaajoukkueessa jäi haaveeksi (rivit 117-127), mutta tämän jälkeen hän lopettaa jälleen positiiviseen huomioon siitä, että kaveri on nyt melko hyvässä kunnossa ja pystyi käymään koulunsa loppuun (rivit 128-132). AS vastaa tähän "joojoo" (rivi 134) ja 1.3 sekunnin tauon jälkeen ottaa puheenaiheeksi kaivinkoneen kauhan painon ja ulkonäön välisen epäsuhdan ("eihä se tota kaivinkonenkaa kauha näy- näytä itseasias yhtään”, rivit 136-139), palaten siten osittain aikaisempaan, tilanteen järjettömyyttä korostavaan toimintalinjaansa.

NT ei odota AS:n pääsyä vuoron loppuun, vaan aloittaa oman luonnehdintansa kauhasta päällekkäispuhuntana: "joo mut se painaa viissataa kiloo $£$ nih£” (rivi 140). "Joo mut" vuoron alussa on myönnyttelevä (Niemi, 2015), mutta NT:n ilmaisema mielipide on selvästi erilinjainen AS:n kanssa. Vuoron päättävä "nih" naurahduksella tuotettuna viittaa myös siihen, että vuorossa on jotain ongelmallista (vrt. Haakana, 1999; 2001). NT korostaakin kaivinkoneen kauhan valtavaa painoa, kun taas AS toistaa oman näkökantansa siitä, että kauha näyttää kevyeltä (rivi 146; toistosta autismikirjon häiriössä ks. Stribling ym., 2006). Pienen tauon jälkeen (rivi 158) AS jatkaa aiheesta ja osallistujat puhuvat tämän jälkeen vielä melko kauan kaivinkoneen kauhan ominaisuuksista (riviltä 159 alkaen).

AS:n vuoro riveillä 136-139 ei affilioi kertomuksen emotionaalista puolta eikä avusta NT:n (mahdollista) projektia puheenaiheen tuomisessa päätökseen. Sen sijaan AS poimii edellisestä aiheesta itseään kiinnostavan puolen (ehkä jopa oman erityisen mielenkiinnonkohteensa), eli kaivinkoneen kauhan materiaalin ja fyysiset ominaisuudet, ja jatkaa topiikkia tästä näkökulmasta. Aiheen erityistä mielekkyyttä AS:lle puoltaa aiheen pitkä ja perusteellinen käsittely (yhteensä 64 riviä), sekä puheenaiheen itsepintainen ylläpitäminen keskustelukumppanin hienovaraisesta vastustamisesta huolimatta. Tämä voi myös liittyä autismikirjoon liittyviin haasteisiin tunnistaa ja tulkita näitä keskustelukumppanin hienovaraisia merkkejä, ja myöskään NT ei tässä tapauksessa tunnista AS:n kontribuutioita mahdollisena affiliaationa (vrt. Koskinen, Stevanovic \& Peräkylä, tulossa). 


\section{Esimerkki 4: Tarinan päätös ja affiliaatio}

\section{$\underline{\text { A1 Kaivinkone 4/4 }}$}

[15 RIVIÄ KESKUSTELUA KAIVINKONEEN KULJETTAJASTA]

\begin{tabular}{|c|c|}
\hline 216 & $(0.9)$ \\
\hline 17 AS: & eiks se oo itseasias tota ollu eikös se oo ollus \\
\hline 8 & tota, (1.0) \#ee\# †niijoo iha: hyvä sitte, (1.1) \\
\hline 9 & 'ttä jossei käyny sen pahemmin mutta [totah [jooh. \\
\hline $0 \mathrm{NT}:$ & {$[\mathrm{mm}$} \\
\hline 21 & $(0.8)$ \\
\hline $2 \mathrm{NT}:$ & ky $[: 11 \ddot{a}$ \\
\hline 3 AS: & [>mut seo- seo- koo- kyllä tota:\#e\#< (0.5) \#te\# \\
\hline 4 & tota (0.3) \#ky:\# kypärän käyttö olis ollu \\
\hline 25 & järkevää kylä a- aikasemminki [(--) \\
\hline $26 \mathrm{NT}:$ & [nii \\
\hline 7 AS: & [sat]tunu jotai. \\
\hline $8 \mathrm{NT}:$ & {$[\mathrm{n}$} \\
\hline
\end{tabular}

Kun kaivinkoneen kauhasta on keskusteltu tarpeeksi, NT tuo keskustelun vielä kerran takaisin ystävänsä tilanteeseen toteamalla, että kyseinen tapaturma oli myös kaivinkoneen kuljettajalle kova paikka (ei näy yllä olevassa katkelmassa). Tämän jälkeen AS aloittaa vuoron (esimerkin rivillä 217) "eiks se oo itseasias tota ollu- eikös se oo ollus tota-", mutta lopettaa aloituksensa kesken. Sekunnin mittaisen tauon jälkeen AS tuottaa koko aiemman tarinan emotionaalista puolta affilioivan vuoron, tosin eräänlaisen välihuomautuksen muodossa: "niijoo iha hyvä sitte, että jossei käyny sen pahemmin mutta totah jooh". "Niijoo" vuoron alussa voi tässä yhteydessä osoittaa, että vuoro ei ole oikealla paikallaan ja olisi voinut tulla aiemminkin. Se saattaa välittää myös tietynlaista "oivaltamista" ja sitä, ettei kertomuksen affektiivinen puoli ole suinkaan jäänyt AS:Ita täysin huomaamatta. "Mutta"partikkeli vuoron lopussa taas ennakoi, että asialla on olemassa myös kääntöpuolensa. AS:n osoittamaa affiliaatiota seuraakin vielä avoimesti sääntörikkomusta korostava vuo- ro "mut kyllä tota kypärän käyttö olis ollu järkevää kyllä aikasemminki” (rivit 223225). AS siis onnistuu poimimaan tarinasta sen emotionaalisen puolen ja osaa tuottaa sitä tukevan affiliatiivisen vuoron, vaikkakin myöhässä ja upotettuna toiseen toimintoon. On mahdollista, että AS-puhujat ylipäätään tarvitsevat enemmän aikaa ja tarinan koko kontekstin, ennen kuin voivat tuottaa affiliatiivisen vuoron. Tästä huolimatta sääntökeskeisyys ja siitä kumpuavat moralisoivat sävyt tuntuvat kuitenkin lopulta syrjäyttävän kerronnan vastaanoton affektiivisen ulottuvuuden.

\section{POHDINTA}

Koska autismikirjon henkilöillä on haasteita sekä kehollisen toiminnan tunnistamisessa että vuorovaikutuksen kontekstin huomioimisessa (APA, 2013), ei liene yllättävää, etteivät he aina tunnista sellaisia hetkiä, jolloin heiltä odotetaan affektiivista yhtymistä vuorovaikutuskumppanin tunnekokemukseen. 
Esittelimme yllä, miten tietyt autismikirjon erityispiirteet - sääntökeskeisyys, paikallissuuntautuneisuus ja egosentrisyys - heijastuvat AS-henkilön vastaanottovuoroihin sellaisissa sekventiaalisissa paikoissa, joissa affiliaation osoittaminen olisi relevanttia. Sääntökeskeisyys näkyy kypärän käyttöön liittyvien suositusten topikalisoimisessa affektiivisen puolen sijaan. Paikallissuuntautuneisuus näkyy erityisesti kohdassa, jossa kertoja mainitsee meneillä olevasta oikeusjutusta, ja AS-henkilö vaihtaa puheenaiheen Bodominjärven murhiin. Egosentrisyyden taas voi nähdä liittyvän sekä kaivinkoneen kauhan fysikaalisten ominaisuuksien topikalisoimiseen että keskustelukumppanin hienovaraisten merkkien huomioimattomuuteen. Kokonaisuudessaan näissä neljässä esimerkkikatkelmassa esiintyvien AS-henkilön vastaanottovuorojen epäaffiliatiivisuus rakentuu varsin saumattomasti autismikirjon vuorovaikutuksen erityispiirteiden seurauksena.

Tietyt vuorovaikutustilanteet tai keskustelukumppanin toiminta voivat kuitenkin myös olla keskeisessä osassa tuottamassa autismikirjon henkilöiden poikkeaviksi kuvattuja toimintoja. Tässä tutkimuksessa esitelty esimerkkitarina voi osaltaan olla erityisen vaikeasti affilioitava, sillä sen aiheena ei ole vain surullinen sattumus, vaan myös onni siitä, ettei käynyt pahemmin. Aiemman psykofysiologiaa ja tarinan vastaanottoa yhdistävän tutkimuksen (Voutilainen ym., 2014) perusteella voidaan olettaa, että tällaiset iloisia ja surullisia asioita yhdistävät, ambivalentit tarinat vaativat tarinan vastaanottajalta mahdollisesti enemmän kognitiivisia ja vuorovaikutuksellisia taitoja kuin yksinomaan iloiset tai surulliset kertomukset. Bavelas ja kumppanit (2000) tutkivat kokeellisesti tällaisten "läheltä piti" (close call) -tarinoiden kerrontaa ja vastaanottoa, ja huomasivat kertojien usein liikkuvan hyvinkin nopeasti erilaisista affektiivisista asennoitumisista toisiin, kuten kauhusta ja dramatiikasta huumoriin. He kuitenkin korostivat koehenkilöinä toimivien neurotyypillisten vastaanottajien taitavuutta ja kykyjä eläytyä kertojan nopeisiin asenteen muutoksiin tarinan sisällä, vaikka kyseessä oli täysin tuntematon kanssakeskustelija (Bavelas, Coates \& Johnson, 2000, s. 944). Toisaalta keskustelunanalyyttisestä näkökulmasta voidaan myös kysyä, missä määrin yllä esitetyn tarinan korostunut "vaihtelevuus" on tarinan itsensä ominaisuus, ja missä määrin se on kertojan ja vastaanottajan toimintojen vuorovaikutuksellinen seuraamus. Yksi klassinen tapa, millä puhujat voivat reagoida puuttuvaan vastaukseen ja hakea responssia, on aiemmin ilmaistun asenteensa (stance) muokkaaminen (Pomeranz, 1984; ks. myös Peräkylä \& Ruusuvuori, 2012).

Tässä tutkimuksessa tarkastelimme affiliaatiota ensisijaisesti osallistujien puheenvuorojen kautta toteutuvana vuorovaikutusilmiönä, mikä on otettava huomioon rajoitteena tutkimuksemme tulosten tulkinnassa. Multimodaalisten keinojen analyysi olisi voinut paljastaa AS-henkilöiden erityisiä kompetensseja ja tapoja ilmaista affiliaatiota, tai vastaavasti syventää analyysiamme AS-henkilöiden epätyypillisestä affiliaatiosta. Lisäksi tutkimuksemme tulosten tulkinnassa on syytä ottaa huomioon keskittymisemme pelkästään affiliaatioon, sen sijaan että olisimme käsitelleet vuorovaikutuksen osallistujien toiminnan samanlinjaisuutta (alignment). Stivers (2008) on tehnyt eron affiliaation ja samanlinjaisuuden osoittamisen välille, jossa samanlinjaisuus liittyy meneillä olevan toiminnan rakenteiden tukemiseen, eli tarinankerronnassa esimerkiksi kertojan ja kertomuksen vastaanottajan epäsymmetristen roolien ylläpitämiseen. Yllä esitellyssä aineistoesimerkissä AS-henkilön voi huomata orientoituvan toimintojen rakenteiden ylläpitämiseen, vaikkakaan affiliaation osoittaminen ei ole yhtä selvää. 
Vuorovaikutuksessa esiintyvät ongelmat eivät siis ole pelkästään yksilöiden puutteista aiheutuvia haasteita, vaan ne rakentuvat osallistujien suuntautuessa vuorovaikutukseen eri tavoin, erilaisia resursseja käyttäen. Tässä tutkimuksessa havaitsimme melko selkeitä epäsymmetrisyyksiä osallistujien rooleissa. Näitä epäsymmetrisyyksiä olisi tärkeä tutkia vielä lisää ja entistä tarkemmin suhteessa keskustelun rakenteisiin. Affiliaation ohittavat vastaanottovuorot voivat pidemmällä tähtäimellä johtaa siihen, ettei vuorovaikutus-

\section{LÄHTEET}

American Psychiatric Association, APA. (2013). Diagnostic and statistical manual of mental disorders (5. painos). Arlington: American Psychiatric Publishing.

Asperger, H. (1944).Die 'autistischen psychopathen' im kindesalter. Archiv für Psychiatrie und Nervenkrankheiten, 117, 76-136.

Attwood, T. (1998). Asperger's syndrome: A guide for parents and professionals. London: Kingsley. Baron-Cohen, S. (2008). Autism and Asperger syndrome. New York: Oxford University Press.

Baron-Cohen, S., Richler, J., Bisarya, D., Gurunathan, N. \& Wheelwright, S. (2003). The systemizing quotient: an investigation of adults with Asperger syndrome or highfunctioning autism, and normal sex differences. Philosophical Transactions of the Royal Society B: Biological Sciences, 358, 361-374.

Baron-Cohen, S. \& Wheelwright, S. (2004). The empathy quotient: an investigation of adults with Asperger syndrome or high functioning autism, and normal sex differences. Journal of Autism and Developmental Disorders, 34, 163-175.

Baron-Cohen, S., Wheelwright, S., Skinner, R., Martin, J. \& Clubley, E. (2001). The autism-spectrum quotient (AQ): evidence from Asperger syndrome/high-functioning autism, males and females, scientists and mathematicians. Journal of Autism and Developmental Disorders, 31, 5-17.

Bavelas, J., Coates, L. \& Johnson, T. (2000). Listeners as co-narrators. Journal of Personality and Social Psychology, 79, 941-952. kumppani kerro vastaavia tarinoita enää jatkossa. Tällä taas voi olla kielteinen vaikutus osallistujien välisen suhteen rakentumiseen (Hobson \& Hobson, 2008). Lisääntynyt ymmärrys vuorovaikutuksen käytänteiden merkityksestä osallistujien toiminnan ja heidän välisensä suhteen rakentumiselle voi auttaa autismikirjoon liittyvien vuorovaikutuksen erityispiirteiden kuvaamisessa sekä rakentaa ymmärrystä erilaisten ihmisten ja vuorovaikutustyylien välille.

Brewer, N., Young, R. L. \& Barnett, E. (2017). Measuring Theory of Mind in Adults with Autism Spectrum Disorder. Journal of Autism and Developmental Disorders, 47, 1927-1941.

Couper-Kuhlen, E. (2012). Exploring affiliation in the reception of conversational complaint stories. Teoksessa A. Peräkylä \& M-L. Sorjonen (toim.), Emotion in interaction, (s. 113-146). Oxford: Oxford University Press.

Dean, M., Adams, G. \& Kasari, C. (2013). How narrative difficulties build peer rejection: A discourse analysis of a girl with autism and her female peers. Discourse Studies, 15, 147-166.

Dickerson, P., Stribling, P. \& Rae, J. (2007). Tapping into interaction: How children with autistic spectrum disorders design and place tapping in relation to activities in progress. Gesture, 7, 271-303.

Diehl, J. J., Bennetto, L. \& Young, E. C. (2006). Story recall and narrative coherence of highfunctioning children with autism spectrum disorders. Journal of Abnormal Child Psychology, 34, 83-98.

Dindar, K., Korkiakangas, T., Laitila, A. \& Kärnä, E. (2016a). Building mutual understanding: How children with autism spectrum disorder manage interactional trouble. Journal of Interactional Research in Communication Disorders, 7, 49-77.

Dindar, K., Korkiakangas, T., Laitila, A. \& Kärnä, E. (2016b). Facilitating joint attention with salient pointing in interactions involving children with autism spectrum disorder. Gesture, 15, 372-403. 
Dobbinson, S. (2015). Conversation with an adult with features of autism spectrum disorder in secure forensic care. Teoksessa M. O'Reilly \& J. N. Lester (toim.), The Palgrave handbook of adult mental health: Discourse and conversation studies. London: Palgrave.

Gillberg, C. (2002). Aguide to Asperger syndrome. Cambridge: Cambridge University Press.

Goffman, E. (1974). Frame analysis: An essay on the organization of experience. London: Harper and Row.

Haakana, M. (1999) Laughing matters. A conversation analytical study of laughter in

doctor-patient interaction. Väitöskirja. Suomen kielen laitos. Helsinki: Helsingin Yliopisto.

Haakana, M. (2001) Laughter as a patient's resource: Dealing with delicate aspects of

medical interaction. Text \& Talk, 21, 187-219.

Heritage, J. (2011). Territories of knowledge, territories of experience: Empathic moments in interaction. Teoksessa T. Stivers, L. Mondada, \& J. Steensig (toim.), The morality of knowledge in conversation, (s. 159-183). Cambridge: Cambridge University Press.

Hobson P. \& Hobson J. A. (2008). Engaging, sharing, knowing: some lessons from research in autism. Teoksessa: J. Zlatev, T.P. Racine, C. Sinha \& E. Itkonen (toim), The shared mind: perspectives on intersubjectivity, (s. 67-88). Amsterdam: Benjamins.

Hobson, P., Hobson, J. A., Garcia-Perez, R. \& Du Bois, J. (2012). Dialogic linkage and resonance in autism. Journal of Autism and Developmental Disorders, 42, 2718-2728.

Holt, E. (1993). The structure of death announcements: Looking on the bright side of death. Text, 13, 189-212.

Jefferson, G. (1978). Sequential aspects of storytelling in conversation. Teoksessa J. Schenkein (toim.), Studies in the organization of conversational interaction, (s. 219-248). New York: Academic Press.

Jefferson, G. (1984). On stepwise transition from talk about a trouble to inappropriately nextpositioned matters. Teoksessa J. M. Atkinson \& J. Heritage (toim.), Structures of Social Action, (s. 191-222). Cambridge: Cambridge University Press.

Jefferson, G. (1988). On the sequential organization of troubles talk in ordinary conversation. Social Problems, 35, 418-441.
Jefferson, G. (2002). Is “no” an acknowledgment token? Comparing American and British uses of $(+) /(-)$ tokens. Journal of Pragmatics, 34, 1345-1383.

Klin, A., Jones, W. \& Schultz, R. (2003). The enactive mind, or from actions to cognition: Lessons from autism. Philosophical Transactions of the Royal Society B: Biological Sciences, 358, 345-360.

Korkiakangas, T. (2018). Communication, Gaze and Autism: A Multimodal Interaction Perspective. New York: Routledge.

Korkiakangas, T. \& Rae, J. (2014). The interactional use of eye-gaze in children with autism spectrum disorders. Interaction Studies, 15, 233-259.

Korkiakangas, T. K., Rae, J. P. \& Dickerson, P. (2012). The interactional work of repeated talk between a teacher and a child with autism. Journal of Interactional Research in Communication Disorders, 3, 1-25.

Korpilahti, P., Jansson-Verkasalo, E., Mattila, M.L., Kuusikko, S., Suominen, K., Rytky, S., Pauls, D. L. \& Moilanen, I. (2007). Processing of affective speech prosody is impaired in Asperger syndrome. Journal of Autism and Developmental Disorders, 37, 1539-1549

Koskinen, E. (2015). Mielen luenta keskustelussa. Sosiologian pro gradu -tutkielma. Helsingin yliopisto.

Koskinen, E., Stevanovic, M. \& Peräkylä, A. (tulossa). Affiliation, topicality, and Asperger's: The case of story-responsive questions. Journal of Interactional Research in Communication Disorders.

Kujala, T., Lepistö, T., Nieminen-von Wendt, T., Näätänen, P. \& Näätänen, R. (2005)

Neurophysiological evidence for cortical discrimination impairment of prosody in Asperger syndrome. Neuroscience Letters, 383, 260-265.

Lindstrom, A. \& Sorjonen, M.-L. (2013). Affiliation in conversation. Teoksessa J. Sidnell, \& T. Stivers (toim.), The Handbook of Conversation Analysis, (s. 350-369). Wiley Blackwell.

Losh M. \& Capps L. (2013). Narrative ability in high-functioning children with autism or Asperger's Syndrome. Journal of Autism and Developmental Disorders, 33, 239-251. 
Markram, H., Rinaldi, T. \& Markram, K. (2007). The intense world syndrome - an alternative hypothesis for autism. Frontiers in Neuroscience, 1,77-96.

Maynard, D. (1997). The news delivery sequence: Bad news and good news in conversational interaction. Research on Language and Social Interaction, 30, 93-130.

Maynard, D. (2005). Social actions, gestalt coherence, and designations of disability: Lessons from and about autism. Social Problems, 52, 499-524.

Muskett, T. \& Body, R. (2013). The case for multimodal analysis of atypical interaction: Questions, answers and gaze in play involving a child with autism. Clinical Linguistics \& Phonetics, 27, 837-850.

Muskett, T., Perkins, M., Clegg, J. \& Body, R. (2010). Inflexibility as an interactional phenomenon: Using conversation analysis to re-examine a symptom of autism. Clinical Linguistics \& Phonetics, 24, 1-16.

Niemi, J. (2015). Myönnyttelyn käytänteitä. Erimielisyysja yhteisymmärryksen rakentaminen vuorovaikutuksessa. Väitöskirja. Helsinki: Helsingin yliopisto.

Nieminen-von Wendt, T., von Wendt, L., Avellan, A. \& Tani, P. (2007). Aspergerin oireyhtymä. Kliininen kuva, diagnostiikka ja kuntoutus (osa 1). Yleislääkäri 3/2007, 15-19.

Nieminen-von Wendt, T., von Wendt, L., Avellan, A. \& Tani, P. (2007). Aspergerin oireyhtymä. Kliininen kuva, diagnostiikka ja kuntoutus (osa 2). Yleislääkäri 4/2007, 10-14.

O’Reilly, M., Lester, J. N. \& Muskett, T. J. (2016). Discourse/Conversation Analysis and Autism Spectrum Disorder. Journal of Autism and Developmental Disorders, 46, 355-359.

Ochs, E., Kremer-Sadlik, T., Gainer Sirota, K. \& Solomon, O. (2004). Autism and the social world: An anthropological perspective. Discourse Studies, 6, 147-183.

Ochs, E. \& Solomon, O. (2005). Practical logic and autism. In R. Edgerton \& C. Casey (toim.), A companion to psychological anthropology: Modernity and psycho-cultural change, (s. 140167). Oxford, UK: Blackwell.

Ochs, E. \& Solomon, O. (2010). Autistic sociality. Ethos, 38, 69-92.
Paul, R., Orlovski, S., Marcinko, H. \& Volkmar, F. (2009). Conversational behaviours in youth with high-functioning ASD and Asperger syndrome. Journal of Autism and Developmental Disorders, 39, 115-125.

Peräkylä, A. (2016). Ilmeet ja eleet. Teoksessa M. Stevanovic \& C. Lindholm (toim.), Keskustelunanalyysi. Kuinka tutkia sosiaalista toimintaa ja vuorovaikutusta, (s. 63-78). Tampere: Vastapaino.

Peräkylä, A., Henttonen, P., Voutilainen, L., Kahri, M., Stevanovic, M., Sams, M. \& Ravaja, N. (2015). Sharing the emotional load: Recipient affiliation calms down the storyteller. Social Psychology Quarterly, 78, 301-323.

Peräkylä, A. \& Ruusuvuori, J. (2012). Facial expression and interactional regulation of emotion. Teoksessa A. Peräkylä \& M.-L. Sorjonen (toim.), Emotion in Interaction, (s. 64-91). Oxford: Oxford University Press.

Pomeranz, A. (1984). Pursuing a response. Teoksessa J. M. Atkinson \& J. Heritage (toim.), Structures of social action, (s. 152-163). Cambridge: Cambridge University Press.

Potter, J. (2004). Discourse analysis as a way of analysing naturally occurring talk. Teoksessa D. Silverman (toim.), Qualitative research: Theory, method and practice, 2nd ed., (s. 200-221). London: Sage.

Routarinne, S. (1997). Kertomuksen rakentaminen. Teoksessa L. Tainio (toim.), Keskustelunanalyysin perusteet, (s. 138-155). Tampere: Vastapaino.

Sacks, H. (1974). An analysis of the course of a joke's telling in conversation. Teoksessa R. Bauman \& J. Sherzer (toim.), Explorations in the ethnography of speaking, (s. 337-353). Cambridge: Cambridge University Press.

Sacks, H. (1992). Lectures on Conversation. Oxford: Basil Blackwell, vol. $1 \& 2$.

Schegloff, E. A. (2007). Sequence Organization in Interaction: A Primer in Conversation Analysis, Volume 1. Cambridge, UK: Cambridge University Press.

Selting, M. (2010). Affectivity in conversational storytelling: An analysis of displays of anger or indignation in complaint stories. Pragmatics, 20, 229-277. 
Seppänen, E.-L. (1997). Vuorovaikutus paperilla. Teoksessa L. Tainio (toim.), Keskustelunanalyysin perusteet, (s. 18-31). Tampere: Vastapaino.

Sidnell, J. \& Stivers, T. (toim.) (2013). The Handbook of Conversation Analysis. Wiley Blackwell.

Solomon, O. (2004). Narrative Introductions: Discourse Competence of Children with Autistic Spectrum Disorders. Discourse Studies, 6, 253-276.

Sorjonen, M.-L. (2001). Responding in conversation: A study of response particles in Finnish. Amsterdam: John Benjamins.

Stevanovic, M. (2016). Prosodia. Teoksessa M. Stevanovic \& C. Lindholm (toim.), Keskustelunanalyysi. Kuinka tutkia sosiaalista toimintaa ja vuorovaikutusta, (s. 100-121). Tampere: Vastapaino.

Stevanovic, M. \& Koskinen, E. (2018). Sosiaalinen vuorovaikutus autismikirjon häiriössä - keskusteluntutkimuksen näkökulma. Aikakauskirja Duodecim, 134, 2120-2126.

Stevanovic, M. \& Lindholm, C. (2016). Sosiaalisen havaitsemisen haasteet. Teoksessa M. Stevanovic \& C. Lindholm (toim.), Keskustelunanalyysi. Kuinka tutkia sosiaalista toimintaa ja vuorovaikutusta, (s. 276-294). Tampere: Vastapaino.

Stevanovic, M., Henttonen, P., Koski, S., Kahri, M., Voutilainen, L., Koskinen, E., Nieminenvon Wendt, T., Tani, P., Sihvola, E. \& Perakylä, A. (2017). On the Asperger experience of interaction: Interpersonal dynamics in dyadic conversations. Journal of Autism, 4. http:// dx.doi.org/10.7243/2054-992X-4-2

Stevanovic, M., Henttonen, P., Koskinen, E., Peräkylä, A., Nieminen von-Wendt, T., Sihvola, E., Tani, P. \& Sams, M. (2019). Physiological responses to affiliation during conversation: Comparing neurotypical males and males with Asperger syndrome. PLOS ONE 14(9): e0222084. https://doi.org/10.1371/journal. pone. 0222084

Stivers, T. (2008). Stance, alignment, and affiliation during storytelling: When nodding is a token of affiliation. Research on Language and Social Interaction, 41, 31-57.
Stivers, T., Mondada, L. \& Steensig, J. (2011). Knowledge, morality, and affiliation in social interaction. Teoksessa T. Stivers, L. Mondada, \& J. Steensig (toim.), The morality of knowledge in conversation, (s. 3-24). Cambridge: Cambridge University Press.

Stribling, P., Rae, J. \& Dickerson, P. (2007). Two forms of spoken repetition in a girl with autism. International Journal of Language \& Communication Disorders, 42, 427-444.

Stribling, P., Rae, J., Dickerson, P. \& Dautenhahn, K. (2006). "Spelling it out": The design, delivery, and placement of delayed echolalic utterances by a child with an autistic spectrum disorder. Issues in Applied Linguistics, 15.

Tager-Flusberg, H. (1996). Current theory and research on language and communication in autism. Journal of Autism and Developmental Disorders, 26, 169-172.

Tani, P., Nieminen-von Wendt, T., Lindberg, N. \& von Wendt, L. (2004). Aspergerin oireyhtymä aikuisiässä. Aikakauskirja Duodecim, 120, 693-698.

Tannen, D. (1984). Conversationalstyle: Analyzing talk among friends. Norwood, N.J.: Ablex.

Voutilainen, L., Henttonen, P., Kahri, M., Kivioja, M., Ravaja, N., Sams, M. \& Peräkylä, A. (2014). Affective stance, ambivalence, and psychophysiological responses during conversational storytelling. Journal of Pragmatics, 68, 1-24.

Wicker, B. \& Gomot, M. (2012). The Asperger syndrome. Oxford Handbooks Online. Noudettu 15.6.2019. http://www. oxfordhandbooks.com/view/10.1093/ oxfordhb/9780195342161.001.0001/ oxfordhb-9780195342161-e-05

World Health Organization, WHO. (1993). ICD-10, the ICD-10 classification of mental and behavioural disorders: Diagnostic criteria for research. Geneva: World Health Organization;

World Health Organization, WHO. (2019). ICD-11 [verkkosivu]. Noudettu 15.6.2019. https://www.who.int/classifications/icd/en/ 


\section{STORY RECEPTION AND AFFILIATION IN AUTISM SPECTRUM DISORDER}

Emmi Koskinen, University of Helsinki, Faculty of Social Sciences

Melisa Stevanovic, Tampere University, Faculty of Social Sciences

The storytelling and narration abilities in autism spectrum disorder have been studied extensively with experimental and conversation analytic methods. Story reception, however, has received less attention. In this study we focus especially on the story reception practices and affiliation of participants with autism spectrum disorder. The dataset consists of ten video recordings of dyadic conversations, where one participant has been diagnosed with Asperger Syndrome (AS), and the other participant is neurotypical. By presenting a conversation analytic case study we demonstrate how three features related to AS (rule-centeredness, local orientation and egocentricity) reflect on the story reception practices and affiliation of AS participants. Increasing the understanding of interactional practices and their effect on the relationship of the participants can help unravel the specific interactional features related to AS and build understanding between different people and their interactional styles.

Keywords: affiliation, asperger, autism spectrum disorder, empathy, story reception, storytelling 